The Fiction of Truth 



\section{The Fiction of Truth}

Structures of Meaning in Narrative and Dramatic Allegory

by CAROLYNN VAN DYKE

Cornell University Press

ITHACA AND LONDON 
Cornell University Press gratefully acknowledges a grant from the Andrew W. Mellon Foundation that aided in bringing this book to publication.

Copyright (C) 1985 by Cornell University

All rights reserved. Except for brief quotations in a review, this book, or parts thereof, must not be reproduced in any form without permission in writing from the publisher. For information address Cornell University Press, I 24 Roberts Place, Ithaca, New York I 4850.

First published 1985 by Cornell University Press.

Published in the United Kingdom by Cornell University Press Ltd., London.

International Standard Book Number 0-80 I 4-1760-0

Library of Congress Catalog Card Number $84^{-1} 5607$

Printed in the United States of America

Librarians: Library of Congress cataloging information appears on the last page of the book.

The paper in this book is acid-free and meets the guidelines for permanence and durability of the Committee on Production Guidelines for Book Longevity of the Council on Library Resources. 
For my parents 
